УДК 330.341 .424

Макогон Ю.В.

доктор економ. наук, професор,

Подунай В.В.

канд. економ. наук

Донецький національний університет

\title{
ПЕРЕДУМОВИ ПЕРЕХОДУ НАЦІОНАЛЬНОЇ ЕКОНОМІКИ УКРАЇНИ НА ЕТАП ПОСТІНДУСТРІАЛЬНОГО РОЗВИТКУ
}

\author{
ПРЕДПОСЫЛКИ ПЕРЕХОДА НАЦИОНАЛЬНОЙ ЭКОНОМИКИ УКРАИНЫ НА \\ ЭТАП ПОСТИНДУСТРИАЛЬНОГО РАЗВИТИЯ
}

\section{PREREQUISITES OF TRANSITION NATIONAL ECONOMY OF UKRAINE TO THE STAGE OF POST-INDUSTRIAL DEVELOPMENT}

\begin{abstract}
В роботі розглянуто відмінні риси індустріальної та постіндустріальної економік. Проаналізовано сучасний стан світової науково-технологічної сфери, виокремлено краӥнилідери за показниками інновачійної діяльності. Визначено місце України в світовому інноваційному просторі, доведено, щуо створення сприятливих умов для розвитку та підвищення ефективності наукової й інноваційної діяльності є пріоритетним завданням державної інноваційної політики розвинених краӥн, адже вплив науково-технічної та інноваційної сфер на розвиток $і$ зростання економічної системи набуває вирішального значення в процесі побудови постіндустріального суспільства. Обтрунтовано, щчо перспективними напрямами розвитку сучасного суспільства в Україні можуть стати наступні галузі: машинобудування; приладобудування; розвиток виробництва обороннопромислового комплексу; розвиток гірничо-металургійного комплексу на базі ресурсозберігаючих, екологічно чистих технологій; розвиток хімічної та нафтохімічної промисловості; інформаційні технології.

Ключові слова: індустріальна економіка, постіндустріальна економіка, інноваційна сфера, технологічний розвиток, промисловість.

В работе рассмотрены отличительные особенности индустриальной $u$ постиндустриальной экономик. Проанализировано современное состояние мировой научно-технологической сферы, выделены страны-лидеры по показателям инновационной деятельности. Определено место Украины в мировом инновационном пространстве, доказано, что создание благоприятных условий для развития и повышения эффективности научной и инновачионной деятельности является приоритетной задачей государственной инновачионной политики развитых стран, поскольку влияние научнотехнической $и$ инновационной сфер на развитие $и$ рост экономической системь приобретает решающее значение в прочессе построения постиндустриального общества. Обосновано, что перспективными направлениями развития современного общества в Украине могут стать следующие отрасли: машиностроение; приборостроение; развитие оборонно-промышленного комплекса; развитие горно-металлургического комплекса на
\end{abstract}


базе ресурсосберегающих, экологически чистых технологий; развитие химической и нефтехимической промылиенности; информационные технологии.

Ключевые слова: индустриальная экономика, постиндустриальная экономика, инновационная сфера, технологическое развитие, промышленность.

The paper discusses the features of the industrial and post-industrial economies. The current state of the world's scientific and technological sphere is analyzed, the country's leaders in terms of innovation is highlighted. The place of Ukraine in the global innovation space is determined, it is proved that the creation of favorable conditions for the development and effectiveness of research and innovation is a top priority of the state innovation policy in developed countries, because the impact of science and technology and innovation sectors for the development and growth of the economic system is crucial in the process of building a postindustrial society. It is proved that perspective directions of development of modern society in Ukraine may be the following industries: machine building; instrumentation; the development of the military-industrial complex; development of mining and metallurgical complex based resource, environmentally sound technologies; development of chemical and petrochemical industry; information technology.

Keywords: industrial economy, post-industrial economy, the innovation sphere, technological development, industry.

Вступ. Сучасний економічний розвиток суспільства багато в чому зумовлений прогресом в науково-технологічній сфері. Поява нових технікотехнологічних засобів виробництва зумовлює становлення нових інституційних форм товарно-грошових, виробничих і суспільних відносин, формує нові стереотипи мислення і моделі економічної поведінки індивідів і груп. Колишні, традиційні методи господарювання індустріальної епохи вже не можуть забезпечити належну комерційну ефективність. Відбувається активний перехід суспільства в інформаційну фазу, а суб'єкти господарювання дію в новому середовищі постіндустріальній економіці.

Формування інформаційного суспільства в індустріально розвинених країнах підкріплюється помітними структурними зрушеннями в економіці, пов'язаними з розширенням масштабів використання IКТ. Сучасні тенденції розвитку світової економіки створюють фундамент для інтенсивного формування інформаційного суспільства.

У сучасній глобальній економіці новітній міжнародний поділ праці тісно взаємодіє 3 етнокультурним розмаїттям організаційних форм i економічної поведінки, що мають різне інституційно-культурне походження. Розвиток національної економіко-галузевої структури, інкорпорованої в глобальну економіку, передбачає врахування та використання етнокультурних особливостей людських ресурсів, особливо їх інноваційного потенціалу.

Проблеми особливостей міжнародного науково-технологічного розвитку та впливу інновацій на розвиток економічних систем в умовах побудову постіндустріального суспільства висвітлені у роботах класиків та представників сучасних течій міждисциплінарних досліджень: В. Гейця [12], 
Дж. Гелбрейта [3], М. Кастельса [5], М. Кондратьєва [6], Дж. Несбіта [9], В Семіноженка [11], Л. Федулової [13], А. Чухна [14], Ю. Яковця [15] та інших вчених.

Постановка завдання. Метою роботи $\epsilon$ аналіз сучасного стану інноваційної складової національної економіки для визначення перспективних напрямів та передумов формування в Україні постіндустріальної економіки.

Методологія. Теоретичну та методологічну основу дослідження становлять фундаментальні положення сучасної економічної теорії, наукові праці вітчизняних i зарубіжних вчених 3 проблем формування постіндустріальної економіки в Україні, використано систему методів і підходів, які забезпечують концептуальну єдність дослідження загальнофілософський метод діалектичного пізнання; метод абстрактнологічного аналізу; методи системно-структурного та економіко-статистичного аналізу та ін.

Результати дослідження. Індустріальна економіка заснована на промисловості. На іiі завершення вказують кілька ознак. По-перше, продовжує знижуватися частка доданої вартості промисловості в структурі ВВП. Подруге, продовжує падати частка зайнятих у промисловості в структурі загальної зайнятості в масштабах країн. По-третє, зменшується вплив капіталу на економічне зростання. Хоча частка промислової економіки знизилася, якісні та кількісні показники індустріальної економіки та промислової продуктивності зросли. Ця зміна дивним чином нагадує зниження ролі сільськогосподарської економіки більше 200 років тому. Постіндустріальна економіка заснована в першу чергу на знаннях і даних. Вона характеризується трьома важливими характеристиками:

1. У національній економіці зростає частка галузей, заснованих на знаннях.

2. У національній структурі зайнятості підвищується частка працівників інтелектуальної праці.

3. Помітно збільшується внесок інновацій в економічне зростання.

Сучасними концепціями постіндустріалізму досі не виділено чітких, однозначних і доказових кількісних критеріїв, які дозволили б визначити, чи досягла певна країна рівень постіндустріалізації. Наприклад, це 50, 60 або 70 відсоткова частка послуг у структурі національного ВВП, що призводить до подальших методологічним неточностей. Мова йде про те, які саме країни можна вважати «вже» постіндустріальному, а які - «ще» немає. Чи можна вважати економіки США, Японії та країн СС «постіндустріальними»? Д. Белл відповідає на це питання суперечливе: «... якщо ми визначимо постіндустріальне суспільство як таке, де стався зсув від промислового виробництва до сфери послуг, то виходить, що Великобританія, майже вся Західна Європа, США і Японія вступили в постіндустріальну епоху. але якщо 
визначити інформаційне суспільство як таке, в якому існують одночасно i науковий потенціал, і здатність до трансформації наукових знань на кінцевий продукт (high tech), то можна вважати, що тільки США і Японія відповідають цій умові» [4]. Тим складніше стає використання подібних критеріїв, а загальна методологічна невизначеність концепції постіндустріалізму створює додаткові перешкоди для спроб практичного застосування цієї теорії до економіки України.

Найчастіше під галузями постіндустріальної економіки розуміються ті, які пов'язані з виробництвом, розповсюдженням та обслуговуванням галузі знань та інформації. Вони включають три головні сфери: виробництво знань (дослідження і розробки), іiі поширення (сфера освіти, інформаційна та культурна індустрії) та обслуговування галузі знань (професійні послуги, деякі види медичних послуг, а також державна і громадянська служби). У 1996 році частка інформаційної складової в національних економіках країн ОЕСР вже перевищувала $50 \%$.

Однією з типових рис постіндустріальної економіки є популяризація інформації та мережевих взаємодій. Спосіб виробництва в цій економіці істотно відрізняється від способів виробництва в індустріальній або аграрній економіці. Якщо в індустріальному виробництві ключову роль відіграють механізація, електрифікація, стандартизація, спеціалізація і великомасштабна економіка, то у виробництві знань на перший план виходять інтенсифікація знань, інформатизація, мережева взаємодія, розвиток сфери послуг, глобалізація та диверсифікація.

Основними ознаками розвитку постіндустріальної економіки є:

1. У сфері виробництва: інтенсивне використання знань і послуг; виробництво зерна нижче, ніж виробництво знань; індустрія знань важливіше матеріальної індустрії; турбота про довкілля;

2. У сфері циркуляції: глобалізація ринку; розвиток віртуальних ринків; швидка зміна ринку; віртуальні гроші; електронні карти оплати;

3. У сфері розподілу: розподіл на основі заслуг і згідно соціальної справедливості; капітал знань та інвестиції рівноправні як критерії розподілу [10].

Проведення моніторингу i аналізу стану наукового потенціалу, фінансового забезпечення, результативності наукової й інноваційної діяльності (особливо це стосується робіт, що виконуються за рахунок бюджетного фінансування) $є$ одним із найважливіших шляхів отримання інформаційно-аналітичної бази як підгрунтя для прийняття оптимальних управлінських рішень щодо розвитку наукового потенціалу, визначення найбільш раціональних підходів до фінансування наукових досліджень й інноваційних проектів, вдосконалення процесів створення і впровадження результатів наукової й інноваційної діяльності. 
Кількісними критеріями ступеня розвитку постіндустріального суспільства відносять такі: видатки на освіту та НДДКР; обсяг експорту інноваційної та високотехнологічної продукції; зовнішня торгівля товарами IKT; кількість зареєстрованих патентів; частка, яку займає країна у світовому ринку інновацій; ефективність фінансових вкладень у сферу НДДКР; кількість та ефективність інноваційно-виробничих структур; частка національних витрат на НДДКР у загальносвітовому показнику; частка виробництва послуг у ВВП, а також частка зайнятих у виробництві послуг трудових ресурсів. Світовими лідерами за таким показником, як внутрішні видатки на НДДКР $є$ Ізраїль, Фінляндія, Південна Корея, Швеція та Японія. За підсумками 2012 р., Україна витрачає на дослідження та розробки 0,9\% від ВВП (рис. 1).

Світовий досвід показує, що створення сприятливих умов для розвитку та підвищення ефективності наукової й інноваційної діяльності $€$ пріоритетним завданням державної інноваційної політики розвинених країн, адже вплив науково-технічної та інноваційної сфер на розвиток і зростання економічної системи набуває на сучасному етапі вирішального значення. Головним механізмом реалізації стратегічних цілей державної інноваційної політики $є$ стимулювання наукової й інноваційної діяльності.

Інтенсивність перебігу глобалізаційних процесів у світовій економіці вимагає від України відповіді на низку важливих економічних викликів, визначальним серед яких $є$ здатність до своєчасного й ефективного впровадження передових досягнень у галузі науки, техніки i новітніх технологій.

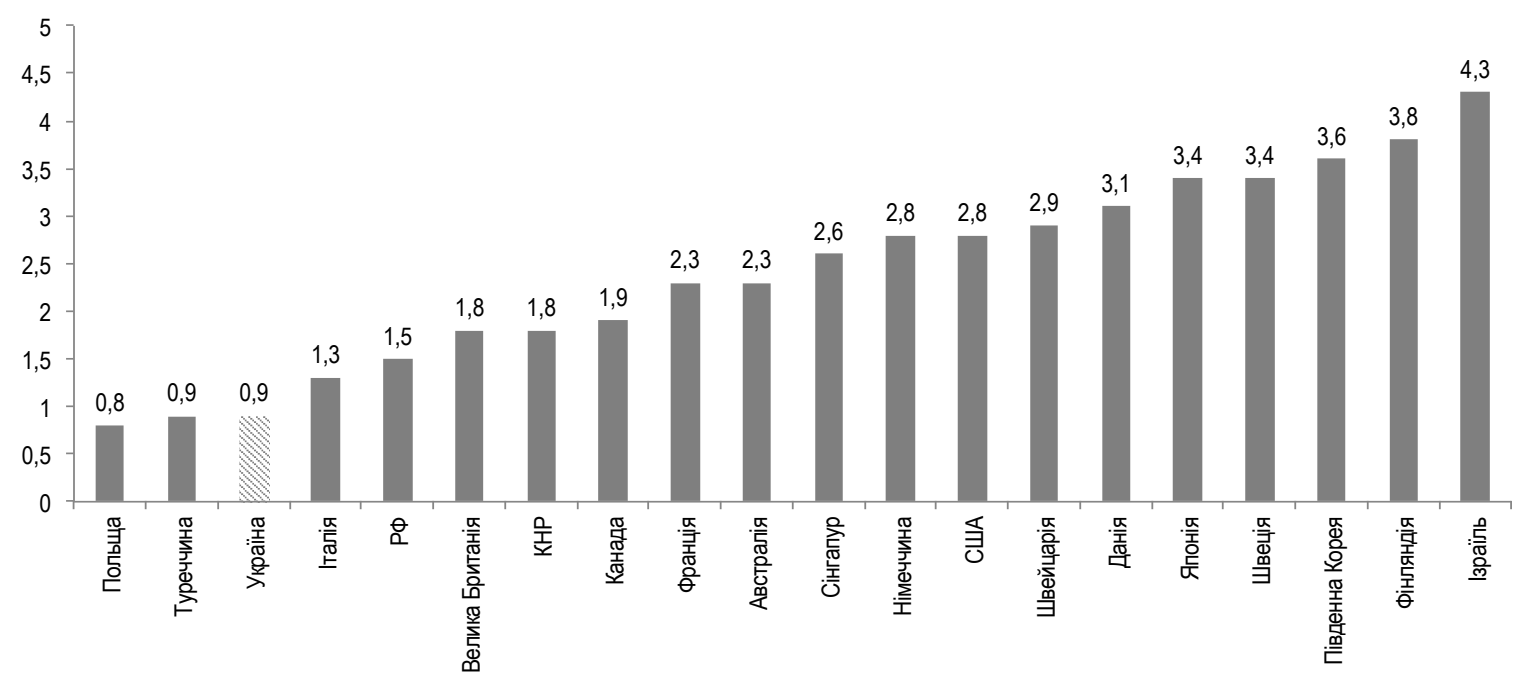

Рис. 1. Внутрішні витрати держав на дослідження і розробки у відсотках до ВВП, 2012 p [1]. 
Підсумки інвестиційного та інноваційного розвитку України останніх років засвідчують підвищення ролі цілеспрямованої державної політики, орієнтованої на підтримку цілісності інноваційного процесу - від наукової розробки до інвестування масового виробництва. Це сприяло покращенню місця України у Глобальному інноваційному індексі (ГІІ) і Глобальному індексі конкурентоспроможності (ГІК). На міжнародному рівні в рейтингу ГІІ 2012 Україна посідає 63 місце серед 141 країн світу проти 60-го місця серед 125 країн світу у 2011 р. До факторів, які визначають якість інноваційної діяльності, можна віднести рівень розвитку вищої освіти й стан сфери досліджень і розробок:

- за рівнем розвитку вищої освіти Україна у 2012 р. посіла 34 місце (39 - у 2011 р.), зокрема за показником охоплення вищою освітою - 8, за часткою випускників наукової та інженерної спрямованості - 19 місце;

- оцінка сфери досліджень і розробок включає 3 показники: кількість дослідників на 1 млн. населення - 44 місце, витрати на R\&D - 37 і якість дослідницьких інститутів - 69 місце;

- за результативністю наукових досліджень Україна у 2012 р. посіла 30 місце (40 - у 2011 р.), зокрема за показниками: зі створення нових наукових знань, що характеризується кількістю патентів та наукових статей - 21 місце, поширення знань - 55, впливу знань - 66 місце[2; 8].

За багатьма науковими напрямами наша країна сьогодні дійсно входить до списку лідерів світової науки. При цьому парадоксальним $є$ той факт, що одночасно із збільшенням активності в інноваційній діяльності, Україна залишилася єдиною державою, яка впродовж багатьох років не мала стратегічно виваженої державної науково-технічної політики, в якій досі не сформовано цілісну інноваційну систему, і де наука практично не задіяна в забезпеченні економічного зростання [4].

Наслідки подібного несумлінного ставлення держави до побудови науково-технічної політики невтішні. Українська наука завдяки активним діям провідних наукових центрів здатна займати лідируючі позиції у світових рейтингах. Але українська держава хронічно відстає від розвинених країн. Більш того, в останні роки це відставання значно поглибилося, що є ознакою експлуатації екстенсивної моделі зростання та інфляції ресурсів інтенсивного розвитку. Тобто того розвитку, який в підсумку і дає нову якість життя, новий рівень виробничої культури, нову структуру економіки [11].

Промисловий потенціал України $є$ одним 3 системоутворюючих елементів національної економічної системи та суспільства в цілому. Вітчизняна промисловість забезпечує $45 \%$ валового випуску продукції та $25 \%$ робочих місць. Промислові підприємства забезпечують значну частку доходів державного бюджету та соціальних фондів, заробітної плати працюючої частини населення, формують інвестиційний потенціал країни, визначають 
спрямованість їі інноваційного розвитку. Однак, незважаючи на це, українська промисловість i надалі залишається технологічно відсталою, а тому неефективною та неконкурентоспроможною. Значний ступінь зносу основних фондів свідчить про використання застарілих та ресурсоємних засобів виробництва, що обмежує реалізацію потенціалу промисловості.

Реалії сучасної економічної ситуації в Україні свідчать, що на відміну від розвинених країн, які до 85-90\% приросту ВВП забезпечують шляхом виробництва експорту високотехнологічної продукції, наша країна, посідаючи за кількістю науковців одне з чільних місць у світі, недостатньо використовує свій інноваційний потенціал. Продовжує деградувати ринок науково-технічної продукції внаслідок незначного попиту на інноваційні розробки через низьку платоспроможність вітчизняних споживачів [4]. Тому становище в інноваційній сфері України досі залишається незадовільним: якщо в розвинених країнах питома вага інноваційно активних підприємств знаходиться в межах 60-70\%, то у нас - близько 12\% (Рис. 2).

Ситуація в промисловості на сьогодні така, що підприємства потребують новітніх технологій, вимагають впроваджень сучасного обладнання. Очікується, що держава стане активно залучати інвестиції в експортоорієнтовані галузі. Перехід від сировинної економіки до інноваційної - одна з найактуальніших тем сьогодення.

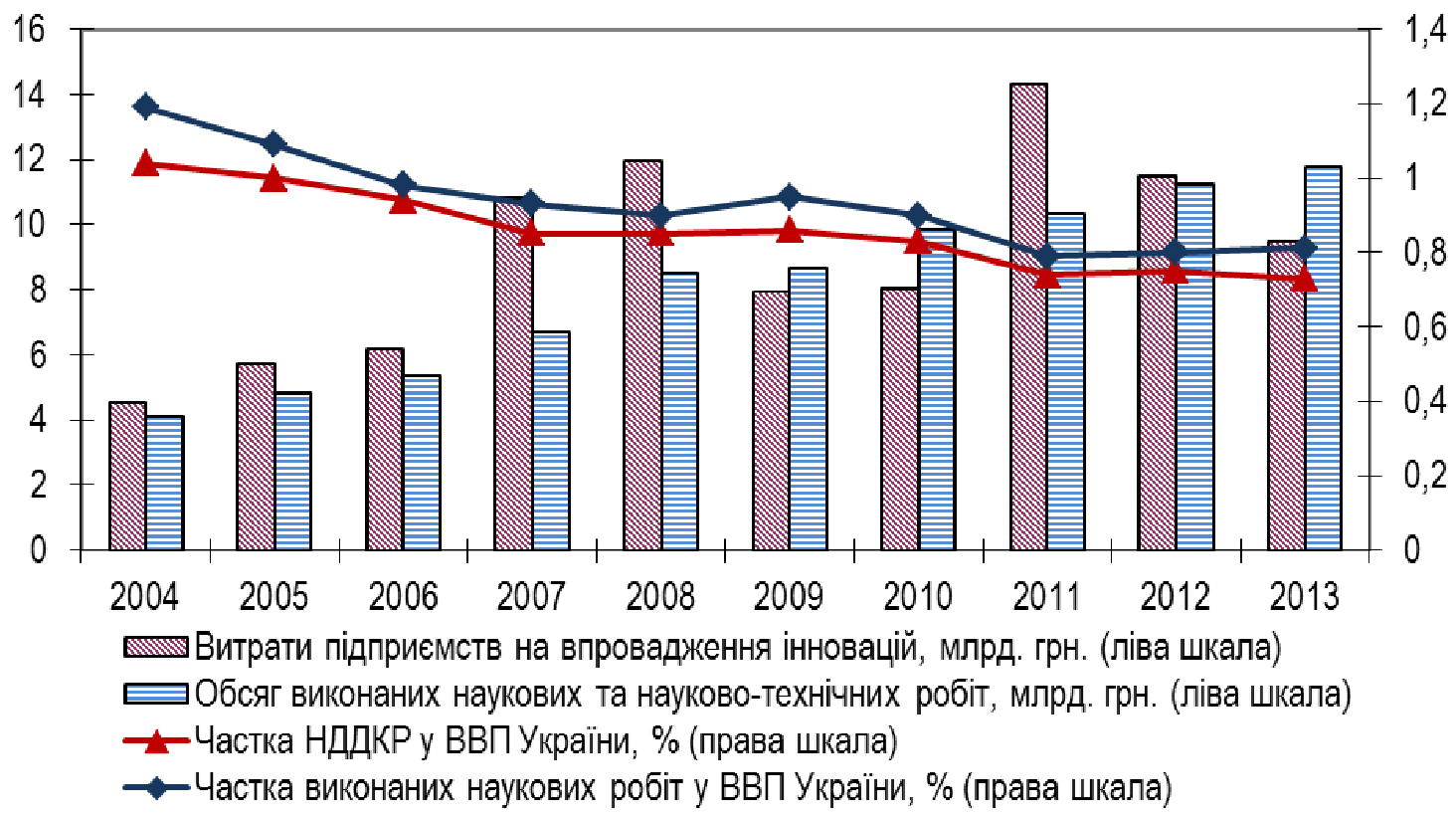

Рис. 2. Інноваційна складова розвитку економіки України у 2004-2013 pp. [4] 
Високий інноваційний потенціал міститься в машинобудуванні, металургії, хімічної та нафтохімічної галузях, що мають найбільші частки інноваційно активних підприємств та є лідерами 3 освоєння виробництва інноваційної продукції та впровадженням нових технологічних процесів. Це пояснюється, насамперед, історично високим науковим потенціалом цих галузей, наявністю кваліфікованих кадрів, високим (порівняно 3 іншими галузями) рівнем витрат на інноваційну діяльність.

Крім вищезгаданої проблематики промисловості України, на динаміку основних експортоорієнтованих галузей впливає i несприятлива зовнішньоекономічна кон'юнктура, яка спостерігається протягом останніх років.

Багатогалузевий машинобудівний комплекс - потужний сектор промисловості України, який займає важливе місце в основних показниках промислового розвитку. Частка галузі в обсязі реалізованої промислової продукції України становила в 2014 р. 11,2\%. У машинобудуванні зосереджено $21,8 \%$ вартості основних засобів та $15,6 \%$ оборотних активів промисловості, в області працює понад $20 \%$ чисельності працівників вітчизняної промисловості.

Машинобудування $\epsilon$ одним 3 лідерів інноваційної діяльності в промисловості України. У 2013 р. частка інноваційно-активних підприємств у галузі становила 24,5\% від загальної кількості підприємств області, що вище середнього по промисловості рівня на 8,3\% [8].

Для України металургія $є$ однією 3 фундаментальних галузей економіки. 70\% металургійної продукції йде на експорт і забезпечує значну частину бюджетних надходжень до державного бюджету, що робить економіку країни надзвичайно чутливою до змін на зовнішніх ринках. Але в результаті низького технологічного рівня металургійних підприємств експорт більш ніж на 50\% становить металопродукція низьких переділів [4].

Хімічний та нафтохімічний комплекс України характеризується наявністю розгалужених зв'язків з іншими галузями економіки, виробляючи продукцію, яка використовується підприємствами металургійної, харчової, легкої промисловості, сільського господарства і т.д. Тому забезпечення інноваційного розвитку хімічної та нафтохімічної промисловості України сприятиме створенню значного синергетичного ефекту в економіці завдяки виготовленню нових і вдосконалених матеріалів, розробки та впровадження передових технологій у виробництві.

Підприємства хімічної та нафтохімічного комплексу України зберігають орієнтацію на виробництво продукції основної хімії з низькою доданою вартістю, тоді як перспективні інноваційні виробництва залишаються нерозвиненими. Підприємства галузі недостатньо використовують потенціал впровадження енерго- та ресурсозберігаючих 
технологій, диверсифікації джерел енергопостачання, а також розвитку малотоннажних виробництв на базі існуючих підприємств галузі.

Нині інноваційні процеси у вітчизняній промисловості мають переважно екстенсивний характер i нові види продукції освоюються в основному шляхом використання науково-технічних надбань попередніх років. Безумовно, такий тип інноваційного розвитку має досить вузькі межі і не дає змоги підтримувати конкурентоспроможність на належному рівні протягом тривалого часу.

Висновки. Отже, основою технологічного розвитку національної економіки та промисловості має стати комплексна модернізація виробництва із запровадженням сучасних досягнень вітчизняної і світової науки й техніки. Пріоритетними галузями промисловості, які можуть забезпечити високий технологічний розвиток Україні, визначені такі:

1) машинобудування (виробництво авіаційної і ракето-космічної техніки, транспортне машинобудування, енергетичне машинобудування, сільгоспмашинобудування);

2) приладобудування (технічне переоснащення систем зв'язку й транспорту, реалізація енергозберігаючих технологій, виробництво діагностичних систем і медичної апаратури, виробництво елементної бази й комплектуючих);

3) розвиток виробництва оборонно-промислового комплексу (виробництво радіолокаційних систем, ракетних систем широкого спектра призначення, засобів радіо- та космічного зв'язку);

4) розвиток гірничо-металургійного комплексу на базі ресурсозберігаючих, екологічно чистих технологій;

5) розвиток хімічної та нафтохімічної промисловості (виробництво гумових і пластмасових виробів, хіміко-фармацевтичної промисловості);

6) інформаційні технології.

Після фінансової кризи наука, технологія і інновації (HTI) вносять життєво важливий внесок у процес стійкого і міцного відновлення економіки і в довгострокові перспективи економічного зростання у всіх країнах світу. НTI можуть відкрити нові шляхи вирішення деяких основних проблем, що стоять перед суспільством: демографічні зміни, глобальні проблеми охорони здоров'я та зміни клімату. Для виконання цих завдань країнам життєво необхідно зберегти продуктивні інвестиції у знання. НТІ ніколи не грали більш важливої ролі.

Економічні події останніх років були джерелом серйозних труднощів в області НТI. Компанії зіткнулися зі зниженням попиту, а також з проблемами наявності кредитування, які підірвали їх зусилля, спрямовані на підтримку інноваційної діяльності. Різке скорочення торгівлі, іноземних інвестицій i доступу до міжнародного фінансування також мали негативні наслідки, які 
відбилися на глобальному ланцюгу вартості, що забезпечує компанії технічними знаннями i досвідом, ринковою інформацією, діловими контактами та міжнародними партнерами.

Розвиток та реалізація науково-технологічного потенціалу промисловості дозволить здійснити позитивні зміни у технологічній структурі промисловості шляхом подолання науково-технологічного відставання, що має здійснюватись в рамках переходу України до стратегії інноваційного прориву. Слід підтримувати інноваційну діяльність підприємств, у рамках розвитку міжнародної кооперації, стимулювати попит на інновації та активне ïx впровадження в промисловості, ліквідувати розрив між наукою i виробництвом, стимулювати комерціалізацію вітчизняних науковотехнологічних розробок на вітчизняних підприємствах, забезпечити патентноліцензійну безпеку вітчизняних компаній.

\section{Лiтература:}

1. OECD Factbook 2013 Economic, Environmental and Social Statistics [Электронный pecypc] // OECD iLibrary. - Режим доступа: http://www.oecd-ilibrary.org/economics/oecdfactbook-2013/expenditure-on-r-amp-d_factbook-2013-60-en.

2. The Global Innovation Index 2012 [Електронний ресурс]. - Режим доступу: http://www.globalinnovationindex.org/gii/main/fullreport/index.html.

3. Гелбрейт Дж. К. Экономические теории и цели общества / Дж. К. Гелбрейт. - М.: Прогресс, 1979. - 406 с.

4. Державний комітет статистики України [Электронный ресурс] // Держкомстат. режим доступу: http://www.ukrstat.gov.ua/.

5. Кастельс М. Информационное общество и государство благосостояния: Финская модель / М. Кастельс, П. Химанен; пер. с англ. А. Калинина, Ю. Подороги. М.: Логос, 2002. - 219 с.

6. Кондратьев Н.Д. Большие циклы конъюнктуры и теория предвидения / Н.Д. Кондратьев. - М.: Экономика, 2002. - 767 с.

7. Макогон Ю.В., Медведкін Т.С. Інноваційний розвиток країни як засіб забезпечення зростання глобальної економічної системи // Теоретичні та практичні аспекти економіки та інтелектуальної власності. - Збірник наукових праць. Маріуполь: ПДТУ, 2013. - С.189-194

8. Науково-технологічна сфера України [Электронный ресурс]. - К.: Державне агентство з питань науки, інновацій та інформатизації України, 2013. - 25 с. - Режим доступа: http://www.dknii.gov.ua/?q=system/files /buklet_2013.pdf.

9. Несбитт Дж. Что нас ждет в 90-е годы: мегатенденции. Год 2000: десять новых направлений на 90-е годы: пер. с англ. / Д. Нэсбитт, П. Эбурдин. - М.: Республика, 1992. $415 \mathrm{c}$.

10. Обзорный доклад о модернизации в мире и Китае (2001-2010): пер. с англ. / под общей ред. Н.И. Лапина; предисл. Н.И. Лапин, Г.А. Тосунян. - М.: Весь Мир, 2011. - 256 с.

11. Семиноженко В. «Инвестиции в новые знания»: Государственное агентство по вопросам науки, инноваций и информатизации Украины. [Электронный ресурс]. - Режим доступа: http://www.dknii.gov.ua/2010-10-05-14-41-28/446-2011-06-20-15-53-59

12. Україна у вимірі економіки знань / за ред. акад. НАН України В.М. Гейця; Ін-т економіки та прогнозування НАН України. - К.: Основа, 2006. - 592 с. 
13. Федулова Л.І. Особливості економіки знань на сучасній фазі розвитку суспільства: теорія і практика розбудови в Україні / Л.І. Федулова, Т.М. Корнєєва // Актуальні проблеми економіки. - 2010. - №4 (106). - С. 73-86.

14. Чухно А.А. Постіндустріальна економіка: теорія, практика та їх значення для України / А.А. Чухно. - К.: Логос, 2003. - 631 с.

15. Яковец Ю.В. Эпохальные инновации XXI века / Ю.В. Яковец. - М.: Экономика, 2004. $-444 \mathrm{c}$. 